\title{
Internationalization of a Software Firm in Colombia Case Study-Sophos Banking Solutions
}

\author{
Sara Marcela Ochoa-Giraldo', GopiKannan Gurusamy², Maria Alejandra Gonzalez-Perez ${ }^{3}$
}

\begin{abstract}
The internationalization phenomenon can be described as the set of processes which helps identifying, entering, establishing and expanding to international markets. Depending on the company and its industry, different internationalization processes might be entertained. This study analyzes the entry modes and market selection strategies followed by Sophos Banking Solutions, a Colombian software company, and also identifies the influencing factors determining their internationalization process. By exploring the existing theories on internationalization and comparing them with the firm's strategy for internationalization, the study identifies whether the firm used the same or different strategy to enter different international markets. The paper also identifies how variables such as managerial influence and network relationships determine the firm's internationalization process. The results illustrate that multiple internationalization theories can be related to the different strategies being followed, but after analyzing the different strategies, we concluded that the firm's internationalization process could be better understood using LLL model.
\end{abstract}

Keywords: internationalization, software firms, colombia, internationalization of services.

\footnotetext{
' Universidad EAFIT, Colombia. Postal address: Calle 34 Nro 64A-30 apto 402, Medellin, Colombia. Phone: +57 30438086 I 3; e-mail:sochoag@eafit.edu.co

2 Universidad EAFIT, Colombia. Postal address: Cra 45 Nro I-59 apto 404, Torre 3, Torres Del Futuro, Medellin, Colombia. Phone: +57 318254 3248; e.mail: gopikannan.g@gmail.com

3 Universidad EAFIT, Colombia. Postal address: Cra 49 Nro 7 Sur 50. Universidad EAFIT. School of Business. Department of Management. BI. 26. Office 4I6. Medellin, Colombia. Phone: +57426I9500 ext.943I; e-mail: mgonza40@eafit.edu.co
}

ISSN: 07 I8-2724. (http://www.jotmi.org) 


\section{Introduction}

In recent decades the software industry has offered opportunities for developing and emerging countries, because of the low capital requirement for international market entry, low trade barriers, high growth and value capabilities and rich in knowledge profile; although developing countries face barriers in establishing the industry, they have a number of notable locational advantages like skilled labor, infrastructure, etc., which should not be ignored (Fredriksson et al. 2012; Lopez et al, 2009; Patibandla and Petersen, 2002).

The spectacular growth of the software industry in some non-G7 economies is a surprising element mostly for countries that are majorly export-oriented. For example, in India, during the 1980s there was literally no software production and after 2000 India sustained an annual growth of $30-40 \%$ year after year in software production (Patibandla and Petersen, 2002). Even though in a lesser degree than India, other countries like Israel and Ireland also showed a double-digit annual growth in software development (Andreosso-O'Callaghan et al, 2014; Arora and Gambardella, 2004; O'Malley and O'Gorman, 200I). It has also been found that the international entry for services and products based firms has been vastly different (Coviello and Martin, 1998; Pla-Barber and Ghauri, 2012). Bell (1995) found that software firms used a variety of market entry modes for performing their first step in the internationalization process, which highlights the impact of international network relationships on the small software firms.Alajoutsijärvi et al., (2000) indicate that small software firms go international mostly based on their relationships with their clients and other firms which have a presence elsewhere. The internet has a great influence by offering various options when deciding on the new market or type of entry along with deciding on the location, and providing a vast platform for business opportunities to software firms (Benjamin and Wigand, 1995). There arise some questions like, what sort of entry mode is adopted by Sophos Banking Solutions to enter international market? And how is the market selection decided?
According to the Information Economy Report by UNCTAD (20I2), the software industry in Colombia shows a low share in economy and low export intensity when compared to the software industry sector of other countries.

The objective of this paper is to identify the internationalization process followed by Sophos Banking Solutions and analyze the entry modes and market selection strategies as well as identify the influencing factors like manager's influence and network relationships in determining heir internationalization process.

To achieve the objectives defined by this research, the article is split into five parts. The first section presents the existing literature available for firm internationalization processes and their theories, which can be used to analyze the case study. The second section explains the methodology followed in this case study to identify the internationalization process and the influencing factors for Sophos Banking Solutions. Moreover, the third section discusses the processed information and the findings of this research article. The fourth section opens up a discussion for the different findings that can be explained by multiple internationalization theories analyzed in the literature. The final section of the article provides the conclusion and final remarks.

\section{Literature Review}

The software industry is considered one of the growing industries with low investment capital requirement and providing services hold vast opportunities for developing countries (UNCTAD, 20I2). However, for technological advancement, it is necessary for countries to build domestic capabilities to allow firms to engage in the learning process (Fredriksson et al. 20I2).

It is a fact that once products are developed by firms, the profits which are earned by these products are considered pure profit, as not much manufacturing effort is required post product creation (Javed et al, 2013; Kittlaus and Clough, 2009). Also these products developed by software firms, are mostly compatible with international markets, thus going international becomes easy for product-based software firms (Suarez et al, 2012). However, firms face difficulties when attempting to do business in an unfamiliar environment or when selling their products to different countries that have a considerable psychic distance from the host country, because it could be a factor that increases the risk of operating abroad or reduce the likelihood of success (Evans and Mavondo, 2002). 
The traditional sequential model of internationalization (Uppsala Model) proposed by Johanson and Valhne (1977), aims at explaining the sequential steps for entering an international market. The Uppsala Model stressed the relevance of knowledge acquisition and learning through a firm's international operations. Later, Johanson and Vahlne (2003) suggested that, in the sequential internationalization process, the network-relationship view plays an important role. The new proposal combined the experiential learning from the old internationalization process model with an experiential learning focused on business network relationships. After understanding the complexity of the market and the environment, Johanson and Vahlne (2009) provided a revised internationalization model.As per the new model, firms strengthen their position within the networks, which results in internationalization. The main difference between the traditional internationalization model and the network model is that the latter does not progress gradually in nature and also the business environment is viewed as a web of relationships.

Xin Guo (20II) identified two important milestones in order to understand the nature of enterprise software and also try to apply internationalization theories to support her analysis:

- How can software firms, understand software products and in turn, the internationalization of the enterprise software product?

- How to implement the internationalization strategies and models to understand the different activities during the process of internalization of the enterprise software product?

Moreover, the study by Patterson and Cicic (1995) brings out various conclusions, of which being the fact that the enterprise software products developed by the software firms are customizable and tangential also the additional services provided by the firms on top of product sales provide them with greater access to international markets and profits. The author uses the revised Uppsala Model, the business network model (Johanson and Vahlne, 2009), when analyzing the internationalization processes of the software firms' product. Johanson and Vahlne (2009) bring out the aspects found below, which needs to be concentrated:

- $\quad$ Opportunities \& Knowledge
- $\quad$ Committed Decisions for Relationship
- $\quad$ Networstanding/Learning, Creating \& Building Trust

Coviello and Munro (1997) analyze how network relationships impact the internationalization process and its patterns. The firms selected for this study were ones that belong to the IT sector. The study offered a conceptual framework to "provide an understanding on how a company's pattern in international growth can be related to their surrounding network processes" (Coviello and Munro, 1997, p.382) and the managerial implications. The software sector can be characterized by inter-firm agreements; this means that in the industry there are some agreements between hardware and software distributors but, taking into account the managerial implications, the results of this study show that managers of this kind of firms need to understand the implications of network relations on the internationalization process as well as be aware of the speed in which this process can take place. Regarding these implications, managers need to have some skills in order to understand the benefits and risks associated with the process according to Guo (20I I). For small software firms, managers play a crucial role in identifying partners to relate with, particularly when bigger firms want to take control over the activities of the smaller ones. These managerial skills are considered to be a key competitive capability.

Arto Ojala (2008) studied how SMEs that have a high knowledge of both the product and the market, and also the internationalization process used by them. Fernahber (2007) affirms that internationalization has been achieved at a high pace for software firms, which are highly based on technology. Moreover, Gonzalez and Cunha (20I2) affirm that the technology capability can be defined by the term "Technology Base" which is nothing but the set of capabilities and the acquired knowledge and skills, on which the firm develops and masters its growth. It has been observed that the academic sector has showed a high attention to the fast internalization of the SMEs that are knowledge-intensive in nature (Ojala, 2008). Taking these reasons into consideration, the author researches the internationalization process of these technology-based firms from different theories, like the "Uppsala model of Internalization, Network Internationalization model and International new venture method (INV)" (Ojala, 2008, p.I3).

According to Ojala and Kontinen (20I0), internalization was viewed as a sequential stage-wise process to be followed based on their experience and commitment in an international market. The Uppsala model claims that the companies tend to move international mostly towards neighboring countries with a similar culture, language and other variables affecting business in the region. Then, once they gain confidence, they tend to move wider, reaching different countries that are geographically more apart. Johanson and Mattsson (1988) provided a different view of the internalization process, describing that a firm starts to go international because

ISSN: 07I 8-2724. (http://www.jotmi.org)

Journal of Technology Management \& Innovation (c) Universidad Alberto Hurtado, Facultad de Economía y Negocios. 
of its relations with other companies, which already have an international presence and connections. The network relationship between different firms barely acts as a catalyst for the internalization process (Johanson and Vahlne, 1990, p.20). The idea behind this model is that firms that have similar objectives actually come together and share their resources to achieve a common goal. This model, however, does not discuss the type of country in which the firms try to enter.

Ojala (2010) proposed that the geographical distance inhibits IT SMEs from entering other markets. It is mentioned that the Uppsala model proposes that long distances inhibit or restrict the flow of information. Regardless, the theory of the Uppsala model argue that the Software SMEs' internationalization does not follow any specific model of internationalization and it shows that most of these companies automatically start the process of export regardless of their geographic proximity to the countries they export to. Overall, the author addressed the following three questions regarding internationalization factors: Distance-Creating, DistanceBridging and Distance-Compressing.

The Distance-Creating factors are psychic, cultural and geographical distance, where distance is defined as "...factors which are disturbing or preventing the information flow between firm and market" (Johanson and WiedersheimPaul, 1975, p.50). The Distance-Bridging Factors are "those factors, which are open to the initiatives by the firms in itself" (Ojala, A., 20I0, p.5I) and according to the Ojala (20I0) the term Distance-Compressing refers to the macro-economic changes, such as technical/technological development, institutional changes, globalization and social movements.

Ojala and Kontinen (2010) used a qualitative method for their study, in which they selected eight Finnish IT companies that had entered the Japanese market. This selection was made because of the cultural and regional differences between the two countries. After the research was completed, the main findings were based on three key points:the Distance-Creating factors have a greater impact on the internationalization process of an IT company and these factors need to be taken into account when a firm decides to enter a new market. Regarding the Distance-Compressing factors they concluded that these are not under a firm's control and as for the Distance-Bridging factors, they facilitate and accelerate the foreign market entry.
Ever since the seminal of Oviatt and Mc Dougall (1994) on the International New Ventures (INV) model/theory, there has been an increased attention to this theory, where the model provides a theoretical explanation of how these companies exist in the international market. INVs begin their international presence because of their commitment to the international arena in multiple countries and they seek growth internationally even before they are founded. Moreover, INVs not only depend on their own resources, but they make use of resources from their network relationship alternatives, a characteristic which distinguishes them from the traditional Multinational Enterprises (MNEs)

Ruokonen and Saarenketo (2007) researched on the strategic categories/orientations that are being adopted in this rapidly internationalizing world of software companies. They studied the following orientations:

$\begin{array}{ll}\text { - } & \text { Entrepreneurial } \\ \text { - } & \text { Learning } \\ & \text { Market }\end{array}$

Ruokonen and Saarenketo (2009) have focused their empirical studies/investigation on the Finnish Software firms, which have shown high levels of internationalization in a short period of time. The Entrepreneurial orientation refers to the firm's ability and willingness to take risks and be proactive and innovative in this competitive market (Ireland et al, 2009). The Learning orientation refers to the firm's beliefs and the practices followed for creating value (Argyris and Schon, 1978). The Market orientation stresses on the companies' values and their attitude towards potential customers and competitors in their respective sector, which they use for their decision-making skills and for maintaining the values instilled by the firm within itself (Slater and Narver, 2000; Kohli and Jaworski, 1990).

Strategic Orientation like learning orientation, entrepreneurial orientation and market orientation as described by researchers depicts the ideas of the firms, which are strategically directed, aimed at achieving performance and maintaining their growth continually (Gatignon and Xuereb, 1997; Gao et al., 2007). Ruokonen and Saarenketo (2009) claim that the orientations tend to change and evolve as the firms develop over time; these orientations, thus, play an important role in the internationalization process. Furthermore, the Entrepreneurial orientation or desire for growth must be embedded into the company's mindset. The authors also claim that the Market and Learning Orientations do not affect the internationalization of a software firm much (Ruokonen and Saarenketo, 2007). 
Rönkkö and Peltonen (2010) argue that internationalization of a software company is considered a natural stage in their life cycle but the way they internationalize changes, depending on the firm. The descriptive conclusions obtained from studying various Finnish software firms, allow the conclusion that companies considered to be hardware manufacturers as well as software developing companies tend to be more likely towards expansion into new markets, whereas the firms offering software services tend to stay more in their home markets. One of the theories for this is that device manufacturers are probably larger than other software firms. Most of the software SMEs tend to internationalize little and gradually and it was commonly observed that such firms target only one or two areas. According to Rönkkö and Peltonen (20I0), Finnish firms that do not have revenues from abroad plan to internationalize depending on their size, but this desire for internationalization can decrease depending on the age of the firm.

Another strategy of internationalization is the phenomenon called born-globals, which is defined as a firm that, since or near its founding, depends or derives substantial percentage/ proposition of revenue from product sales outside its home market or in international markets (Oviatt and McDougall, 2005). The research of Fuerst (2010) is focused on a Colombian software company that internationalized since its beginning. The research applied the model called GMS (Global Marketing Strategy) to the selected company. This company is a SME that develops software using a tool that seems to be a unique product. The GMS model becomes a framework adequate to analyze small born global software firms and the relevant elements are global marketing strategies and global orientation of the software company (Fuerst, 20I0).

The Uppsala Theory explains how a firm concentrates / intensifies its operations into foreign markets (Johanson and Vahlne, 1977), with the following being the key points:

\footnotetext{
- Gains experience from local markets

- Starts foreign operations in countries which are culturally \& geographically closer

- Expands operation in countries more distant from home

- Starts its foreign operations traditionally through trading (exporting)

- Intensifies its operations through sales subsidiaries
}

The changes in factors such as the regulatory and economic environment, the behavior of the firms, their business practices and theoretical research advances and the business network views lead us to revisit the Uppsala Internationalization process (Johanson and Vahlne, 2009). Markets are seen as networks of relationships, where the firms are linked in different patterns with learning, building trust and commitment becomes a pre-requisite for network relations in internationalization markets Johanson and Vahlne, 2009). A firm well established into a network is known as an "Insider". Johanson and Vahlne (2009) argue that insider-ship is necessary but on its own insufficient to become successful.

An "Outsider" does not have any relevant position within a network and a firm trying to enter new markets without network relations might end up suffering from the liability of its outsider-ship. It is necessary for an "Outsider" to establish a relationship with an initial "Insider" making it possible for firms to create opportunities in the foreign market (Johanson and Vahlne, 2009).

According to the Non Sequential Internationalization model, a firm that develops useful knowledge to overcome the difficulties in foreign expansion is most likely to adapt the Non-Sequential Internationalization model (CuervoCazurra, 20II).When it comes to country selection, in terms of the Non Sequential Internationalization model, firms enter more diverse countries easily with different business and institutional conditions, an entry possible because they might have an alliance with a foreign company in their home country, or they might be operating in business to business environments and have great experience in managing multiple operations in their home markets (Cuervo-Cazurra, 20l I).

John A. Mathews (2006) offers the LLL (Linkage, Leverage \& Learning) model which can be summarized as follows: firms from emerging markets might not depend on the assets which they possess, but rather on their ability to link with the international network and leverage their capabilities so as to increase their organizational knowledge by continuous learning (Yamakawa et al. 2008). In addition, for knowledgebased firms, innovation becomes an important aspect, which facilitates them to produce high-technology products and provides high quality services, as knowledge is their major asset and resource (Maldonado et al. 2009). 
The software industry may follow a different internationalization process depending of several variables. Analyzing the case of Sophos Banking Solutions, the main business of which revolves around providing specialized comprehensive information technology services and business process outsourcing, designed to meet the needs of their clients in different sectors of the industry. Having analyzing the existing literature we will analyze how Sophos Banking Solutions has developed their strategies and processes for internationalizing, in terms of entry modes and country selection and CEO influence on decision-making and also determine if the firm is following any of the specific models of internationalization already discussed above.

\section{Methodology}

The objective of the paper is to identify the internationalization process followed by Sophos Banking Solutions and analyze the entry modes, market selection and international consolidation strategies and also identify influencing factors such as managerial influence and network relationships in determining their internationalization process. Since the research is based on findings from a single firm, the strategy adopted to address this question is to conduct a Case Study. According to Gerring (2004, p.34I), a case study is

"best defined as an intensive study of a single unit with an aim to generalize across a larger set of units"

Research Strategy and Types of Evidence:The methods used to collect information were use of questionnaires, face-toface interviews and researching the history of the company. A questionnaire can be explained as follows:

"questionnaires are more suited to issues where there are only a few questions that are relatively clear and simple in their meaning, and the choice of replies can be limited to fixed categories" (Phellas et al. 20I I, p. 183).

The questions were designed with an aim to collect specific data regarding the internationalization strategies followed by Sophos Banking Solutions, with respect to their entry modes, market selection strategies and other influencing factors that could be identified. After collecting the answers, a face-to-face interview was conducted to collect additional information and understanding about the answers found in the questionnaire; this gives room to the respondent to provide reasoning in detail about certain information that cannot be explained in the questionnaire. The reason for using a face-to-face interview has been explained by Phellas et al. (201 I):
"Interviews have certain advantages over self-completion questionnaires. The interviewer can explain questions that the respondent has not understood and can ask for further elaboration of replies (e.g. "Why do you say that?')" (Phellas et al., 20I I, p. I82).

We have proposed using both questionnaire and face-to-face interview in order to gain the advantages of both methods; the questionnaire was chosen for being a more objective and standardized way of collecting the required data and the interview helped gather reasons for the answers provided in the questionnaire.

For this research one of the founders of Sophos Banking Solutions was considered, as he would be the right person to answer the questions on company strategies and decisionmaking capabilities on internationalization processes. He was first provided with the questionnaire to be answered over e-mail and then a face-to-face interview was conducted for reasoning his answers. The information collected was processed by performing a qualitative analysis based on the questionnaire answers provided and the reasons behind choosing those answers. This paper follows a qualitative research pattern, in which the answers and the narrative information have been transferred and transcribed carefully to accommodate similar patterns in the internationalization theories reviewed earlier. As narration is based on experience, it provides a description on tacitly acquired personal knowledge, which does not abandon the context and the complexity (Conle, 2000). The data collection process took place in December 2013. 


\section{Findings}

Four ambitious Indian entrepreneurs namely Atul Malhotra, Amitt Agarwal, Mohan Subramaniam and Kaushal Sheth started Sophos Banking Solutions in Colombia in 2007, having specialized in implementing Core Banking products and providing software development, consultancy and maintenance services for the banking sector.This specialization they gained over several years when they were working with other employers prior to starting Sophos Banking Solutions. In 2007, the founders of Sophos Banking Solutions were presented with an opportunity from one of their banking clients in Colombia to start a company and provide their services, which they acknowledged and commenced their operation with just four employees (themselves); however, the company now employs around two hundred and fifty employees and they have internationalized by supporting the software departments of various banks in the countries where they have presence, through the quality of their work and their commitment to their clients. Table I gives an insight of Sophos Banking Solutions Income Details over the past few years.
The Sophos Banking Solutions sales figures for 2012 stand at around II 479000 USD. They have shown a $44 \%$ annual growth in recent years (Sophos Corporate Presentation). As per ComputerWorld (2013) Report, Sophos Banking Solutions is among the top 10 Software firms founded in Colombia with respect to their revenues. Sophos Banking Solutions has strategic tie-ups with a few leading software providing firms (Partners), which helps them venture into different markets, as the partner software firm is already into international market. Furthermore, Sophos Banking Solutions has clients and operations in Colombia, Mexico, Panama, Chile, Iran and Ukraine. Their internationalization time-line is shown in Figure I:

\begin{tabular}{|l|r|r|r|r|r|}
\hline \multicolumn{5}{|c|}{ Thousands (USD) | Annual| Report details | } \\
\hline Income Statement & \multicolumn{1}{|c|}{2012} & \multicolumn{1}{|c|}{2011} & \multicolumn{1}{c|}{2010} & \multicolumn{1}{c|}{2009} & \multicolumn{1}{c|}{2008} \\
\hline Sales & 11479 & 7705 & 3909 & 1213 & 847 \\
\hline Administrative and General Expenses & 25 & 5 & 3087 & 1194 & 642 \\
\hline Operational Profit & 2125 & 1228 & 807 & 35 & 204 \\
\hline Net Income & 1520 & 874 & 548 & 17 & 148 \\
\hline
\end{tabular}

Table I: Sophos Banking Solutions Income Statement. (Source: EMIS Benchmark, 20I4)

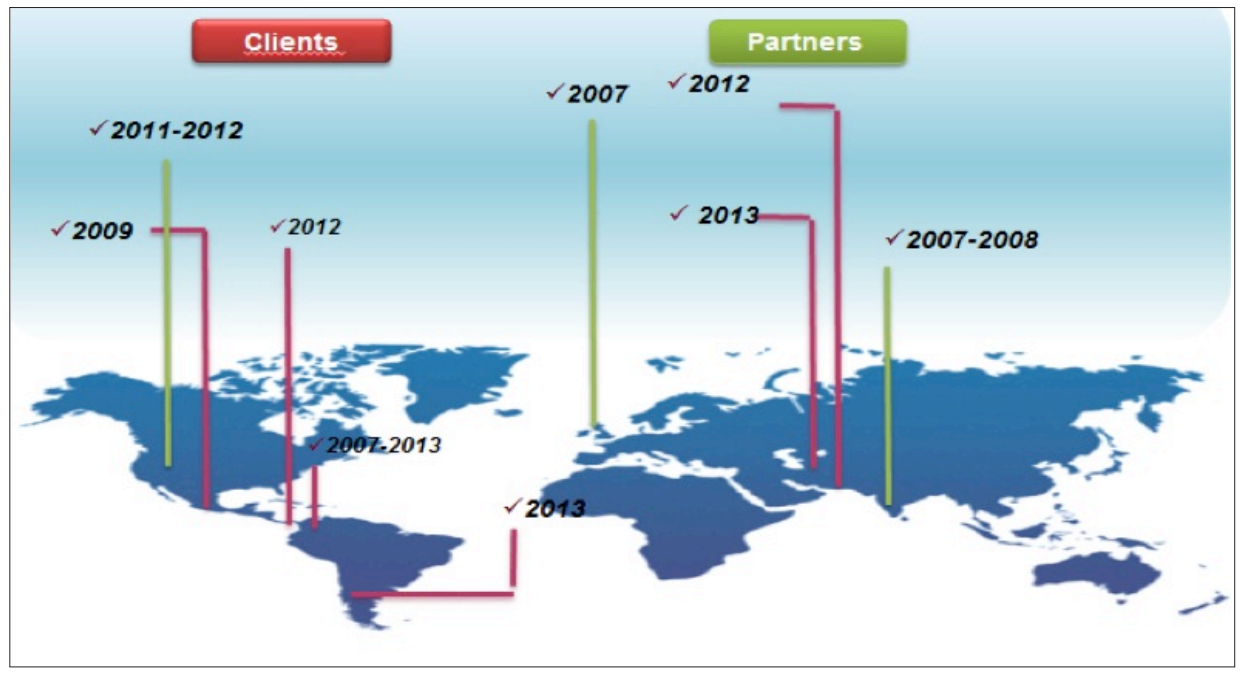

\begin{tabular}{|c|c|c|}
\hline Year & $\begin{array}{c}\text { Client } \\
\text { Countries }\end{array}$ & $\begin{array}{c}\text { Partner } \\
\text { Countries }\end{array}$ \\
\hline 2007 & Colombia & India, UK \\
\hline 2008 & & India \\
\hline 2009 & Mexico & \\
\hline 2010 & & \\
\hline 2011 & & US \\
\hline 2012 & Ukraine, Iran & US \\
\hline 2013 & $\begin{array}{c}\text { Chile, } \\
\text { Panama }\end{array}$ \\
\hline
\end{tabular}

Figure I: Internationalization Time Line (Source: Sophos Corporate Presentation)

ISSN: 07 I8-2724. (http://www.jotmi.org)

Journal of Technology Management \& Innovation (c) Universidad Alberto Hurtado, Facultad de Economía y Negocios. 
Based on the qualitative analysis conducted with the information collected in accordance with the internationalization theories, the following can be deduced:

\section{Market Entry Mode}

The company's key strategy as exclaimed by one of its directors, is acquiring knowledge on some of the world's best banking software products, which in turn enables them to provide services to particular clients with such software products being implemented. This knowledge acquisition aligns perfectly with the company's vision, which states:

"We will be leader in implementation of global recognition BFSI sector products (Banking, Financial Services and Insurance), which allow our customers to compete successfully in an increasingly dynamic and globalized market" (Sophos Banking Solution, 20I4)

This niche has helped them get clients in Colombia, as well as in other countries. They have also gained this advantage by hiring resources of this particular knowledge, as well as training other resources to this specific knowledge. With this, we can identify that their major entry mode for foreign markets is through exporting software services and providing expert consultation abroad. Going further, questioning about their future international expansion mode, it is apparent that they are trying to build foreign subsidiaries in addition to their traditional exporting model. Furthermore, as told by the director, the company concentrates only on a few geographical areas, which are near to the host country, giving them adequate control on the projects. However, the company would not regret venturing into a completely different geographical market, provided that their current market establishments are secured properly.

\section{Home Advantage}

Analyzing their success story with respect to Colombia, they have in total of 27 clients to their credit worldwide, out of which 22 are located in Colombia. This explains the company's home market advantage and their organizational strength, which in turn helps them gain experience in local markets and consequently adapt to new foreign markets. In this sense, the home market advantage together with their organizational and banking knowledge provide them with an edge over other software firms in the country.

\section{Country Selection}

With respect to their strategy on selecting the country for internationalization, they tend to prioritize on their opportunities. When questioned on this subject, the list below was deduced, starting from the number one priority:

- Opportunity within home country (Colombia)

- Opportunity in a country close to home country (e.g. Mexico, Panama)

- Opportunity in a country which is culturally close but physically more distant from home country (e.g. Spain)

- Opportunity in a country which is both culturally and physically more distant from home country (e.g. Ukraine)

There was a special mention of the market size in the country as well, which means that they would consider/prioritize the country that has a bigger market size. When looking at the countries where they already can be found, there seems to be a slight shift from their strategy, with Mexico being the first country outside home and Ukraine and Iran being the countries to follow. The reason provided for his behavior was that it was a director's decision based on relations he had previously established.

\section{Manager's Influence \& Network Relationship}

As discussed in the previous section, the company's presence in foreign countries had a shift when compared to their followed strategy. This was mainly because of the manager's huge influence in decision-making and his network relationships that he holds due to his prior experience in the field. Also the company's directory clearly mentions that one of their main strategies for internationalizing was the acquisition of international relationships through their experience. The company was an 'Insider' within an international relationship network, which they used as catalyst for creating and discovering more business. 


\section{Reasons for Internationalization}

The questions regarding the internationalization strategies followed by this firm triggered us to question on the need and the reason for the company to expand internationally.

We could link the answer with the LLL model of internationalization technique, where the company focuses mainly on Leverage of their knowledge in banking and software industry and Linking with other international relationship networks for more business while continuing their niche by Learning about software products and building trust and relationships with clients and other stakeholders of the network. As answered by the director of the company, the major reasons for them to go international are given below:

- $\quad$ Saturated home markets

- Leveraging home advantage/knowledge to move international

\section{Discussion}

Having a closer look at this research on Sophos Banking Solutions, we could see that the different strategies of the company can be linked to different internationalization model; this behavior initiates a question worth discussing. With respect to Sophos Banking Solutions, gaining local experience and advantage from their activities and operations in their home country (Colombia), and using this when moving into a foreign country (Mexico), which is culturally and geographically close to their home country, can be explained by the Uppsala Model (1997).

As per the country selection strategy followed by Sophos Banking Solutions, we could see the countries to which they moved, after their initial internationalization, were Ukraine and Iran instead of countries close to their home (Colombia); this phenomenon could not be explained by the traditional Uppsala Model. Instead, the revisited Uppsala Model or Network Model (2009) can explain this behavior, where the company used their network relationships and the trust and commitment that the founders built over time, to move to countries more distant from their home. The revisited Network Model explains the business network view of the internationalization process, where the markets are seen as networks of relationships between different firms having trust and commitment as pre-requisite for such network relations (Johanson and Vahlne, 2009).

However, this phenomenon of moving into distant countries like Ukraine and Iran can also be explained by the Non Sequential Internalization model, as Sophos Banking Solutions used the knowledge gained in their home country to overcome the difficulties which they might face during foreign expansion into more diverse countries. As per the Non Sequential Internalization model, a firm which developed useful knowledge to overcome potential foreign expansion difficulties is most likely to enter more diverse countries easily with different business and institutional conditions (Cuervo-Cazurra, 20l I).

We could see that the strategies followed by Sophos Banking Solutions can easily be understood under the lenses of more than one internationalization process theories, like the Uppsala Model, the Network model and the Non Sequential Internationalization model. It raises the question of lack in one single theory to explain this sort of behavior, because seeing the company's behavior in practical terms; their strategy could not be explained by any of the existing internationalization theories.

\section{Conclusions}

To conclude, this research provides an understanding of the internationalization process followed by Sophos Banking Solutions. The study concentrates on a qualitative data collection and analysis aiming to identify the different strategies and patterns followed by this firm in the software industry. The study would help firms that concentrate both on a services-oriented approach and a product-based approach for their internationalization processes. This paper could also serve as a starting point for further research, as it does not provide any concrete conclusions on the internalization process to be followed, but only the overall idea on software firms strategies followed for international expansion, as the processes mentioned here might vary from firm to firm. For IT companies in general, the internationalization process is not a single process to follow; it depends on many factors, as noted both in the literature review and in the company analysis.

Concluding the research conducted on Sophos Banking Solutions, it is possible to see that the firm mostly concentrates on leveraging their home advantage, by carrying over their local market experience and advantage to foreign markets. They concentrate hugely on foreign operations by traditionally exporting resources, knowledge and consulting services in countries that are culturally and geographically closer to home, and also by trying to establish foreign subsidiaries, where they try to follow the traditional Uppsala Model internationalization technique. However, their presence in more diverse countries (Ukraine and Iran when compared to Colombia according to physic distance and culture) tends to convey a different paradigm than the one being followed here. This behavior of country selection for internationalization can be linked to the Non-Sequential model of internationalization (Cuervo-Cazurra, 20I I), where 
the firm tends to go non-sequential because of their local market experience and the manager's influence on network relationships and decision making. Hence, the firm takes mostly some key points of the Uppsala Internationalization model for internationalization process (Johanson and Valhne, 1977; Johanson and Valhne, 2009); as their network relationships and manager's influence may have precedence over this model, this urges them to break the traditional Uppsala Approach and take another characteristic of the Non-Sequential approach. Hence, looking at all their strategies, it was found that they mostly used their knowledge and network relations to move international. Consequently, we concluded that Sophos Banking Solutions is following the LLL (Linkage, Leverage \& Learning) model of Internationalization.(Matthews, 2006).

As we can see, the research study is conducted on only one software firm from Bogota (Colombia), in order to identify the internationalization strategy followed, and from this conclusion, we cannot deduct whether all the Colombian software companies also follow the same internationalization strategies as this company. Still, this research could well serve as starting point for further indepth study of the internationalization process of the entire software industry in Colombia, or can guide and help new software firms with their internationalization strategies. This limitation of the current research opens doors for further research and studies. Furthermore, this research does not contribute to advance the existing internationalization theories, however provides empirical evidences of the internationalization process of a software industry from an emerging market (Colombia). Also this discussion opens up a new front for future research, since we found a lack of one single internationalization framework to explain the company's internationalization strategies.

\section{Acknowledgements}

We would like to thank our family members, friends and classmates for their immense support and encouragement in making this paper possible. Most importantly, none of these would have been possible without the love, affection and patience shown by our parents and family members; particularly we would like to mention Ani Maslin, Aarlene Milinda, Rocio Giraldo, Hector Ochoa and Daniel Ochoa, who have shown great concern and support to this paper and dealt with our odd timelines with no regret.Thanks to all the professors and Thomas Treutler, MIB director/coordinator at Universidad EAFIT for supporting and educating us throughout the course.Thanks to Sophos Banking Solutions and the director MrAtul Malhotra, for providing quality time amidst his schedule to answer our questions and narrate his experiences. Without all your contributions, this paper would never be possible; our sincere thanks to "one and all". 


\section{References}

ALAJOUTSIJÄRVI, K.; Mannermaa, K.; Tikkanen, H. (2000). Customer relationships and the small software firm - a framework for understanding challenges faced in marketing. Information \& Management, 37 (3), 153-159. doi: 10.1016/ S0378-7206(99)00039-7.

ANDREOSSO-O'CALLAGHAN, B.; Lenihan, H.; Reidy, P. (20I4) The development and growth of the software industry in Ireland:An institutionalized relationship approach.European Planning Studies. doi: I0.1080/096543 |3.20|4.892572

ARORA, A.; Gambardella, A. (2004). The globalization of the software industry: perspectives and opportunities for develop and developing countries. National bureau of economic research. Innovation Policy and the Economy, 5 (2005), The MIT Press. doi: I0.3386/w 10538

ARGYRIS, C.; Schon, D. (1978). Organizational Learning: A Theory of Action Perspective, Addison-Wesley, Reading, MA.

BELL, J. (1995). The internationalization of small computer software firms - a further challenge to 'stage' theories. European Journal of Marketing, 29 (8), 60-75. doi: 10.1108/03090569510097556

BENJAMIN, R.; Wigand, R. (1995). Electronic markets and virtual value chains on the information superhighway. Sloan Management Review, 36 (2), 62-72 Available online at: http:// sloanreview.mit.edu/article/electronic-markets-and-virtualvalue-chains-on-the-information-superhighway/ [Accessed September 12th 2014]

COMPUTERWORLD (2013) 50 Grandes de la Informática. Available online at http://computerworld.co/imagenes/ cw430mayo.pdf [Accessed September 12th 20I4]

CONLE, C. (2000). Narrative Inquiry: Research Tool and Medium for Professional Development. European Journal of Teacher Education, 23(I), 49-63. doi: 10.1080/7/3667262

COVIELLO, N.; Martin, K. (1998). Internationalization of service SMEs: an integrated perspective from the engineering consulting sector. Journal of International Marketing, 7 (4), 42-66. Stable URL: http://www.jstor.org/stable/25048785

COVIELLO, N.; Munro, H. (1997). Network Relationships and the Internationalization Process of Small Software Firms. International Business Review, 6(4), 361-386. doi: 10.1016/ S0969-593I(97)000I0-3
CUERVO-CAZURRA, A. (20II). Selecting the country in which to start internationalization: the non-sequential internationalization argument. Journal of World Business, 46(4), 426-437. doi. 10.1016/j.jwb.2010.10.003

EVANS, J.; Mavondo, F.T (2002) Psychic distance and organizational performance: An empirical examination of international retailing operations. Journal of International Business Studies, 33 (3), 5I5-532. Stable URL: http://www. jstor.org/stable/3069528

FREDRIKSSON, T.; Barayre, C.; Fondeur, S.; Jang, S.; Korka, D.; Lang, R.; Lakhe, S. (20/2).Information Economy report. The software industry and developing countries. UNCTAD: New York, NY. Available online at: http://unctad.org/en/ PublicationsLibrary/ier2012_en.pdf. [Accessed September I2th 20I4]

FUERST, S. (2010). Global marketing strategy: The case of a born global software firm in Colombia. Revista Ciencias Estratégicas, 18, 27I-286. Available online at: http://revistas. upb.edu.co/index.php/cienciasestrategicas/article/view/7/2. [Accessed September 12th 2014]

GAO, G.Y.;Zhou, K.Z.;Yim, C.K.(2007). On what should firms focus in transitional economies? A study of the contingent value of strategic orientations in China. International Journal of Research in Marketing, 24 (I), 3-15. doi: 10.1016/j. ijresmar.2006.09.004

GATIGNON,H.; Xuereb,J-M.(1997). Strategic orientation of the firm and new product performance. Journal of Marketing Research, 36 (I), 77-90. doi:10.2307/3152066

GERRING, J. (2004). What is a Case Study and What is it Good for?. American Political Science Review, 98 (2), 34I 354. doi: $10.1017 /$ S000305540400II82

GONZALEZ, R.; Cunha, S.K. (20I2) .Internationalization Process and Technological Capability Trajectory of Iguaçu. Journal of Technology Management \& Innovation. 7 (2), II 7 |30 . doi: |0.4067/S07|8-272420|20002000|0

GUO, X. .(20II). Internationalization of Enterprise-solution Software. KTH Industrial Engineering and Management. http://www.diva-portal.org/smash/get/diva2:4 I6846/ FULLTEXTOI.pdf [Accessed April 28th 2014]

IRELAND, R.D., Covin, J.G., Kuratko, D.F. (2009) Conceptualizing corporate entrepreneurship strategy. Entrepreneurship Theory and Practice. 33(I), 19-43. doi: I0.1 III/j. I540-6520.2008.00279.x 
JAVED, A.; Ullah, M.A., Rehman, A.U. (20I3) Factors affecting software cost estimation in developing countries. International Journal of Information Technology and Computer Sciences. 5(5), 54-59. doi: I0.58I5/ijitcs.20I3.05.07

JOHANSON, J:; Mattsson, L.G. (1988). Internationalization of Industrial Systems - A Network Approach. In N.Hood and J.E. Vahlne (Eds.) Strategies in Global Competition, London: Croom Helm, 187-3/4

JOHANSON, J.; Vahlne, J.E. (1977). The internationalization process of the firm- a model of knowledge development and increasing foreign market commitment. Journal of International Business Studies, 8 (I), 23-32. doi:10.1057/ palgrave.jibs. 8490676

JOHANSON, J.; Vahlne, J.E. (2003). Business relationship Learning and commitment in the internationalization process. Journal of international entrepreneurship, I, 83-I0I. doi: I0.1023/A: 023219207042

JOHANSON, J.; Vahlne, J.E. (2009). The Uppsala internationalization process model revisited: From liability of foreignness to liability of outsider ship. Journal of International Business Studies, 40, I4II-1431. doi: 10.1057/ jibs.2009.24

JOHANSON, J:; Widersheim - Paul, F. (1975). The internationalization of the firm: Four Swedish Cases. Journal of Management Studies, 12 (3), 305-322. doi: I0.1 I I I/j. I4676486. I 975.tb005I4.x

KITTLAUS, H.B.; Clough, PN. (2009). Software Product Management and Pricing: Key Success Factors for Software Organizations. Springer-Verlag Berlin Heidelberg, 17-37. doi:10.1007/978-3-540-76987-3

KOHLI, A.K.; Jaworski, B.J. (1990). Market orientation: the construct, research propositions, and managerial implications. Journal of Marketing, 54 (2), I-I8. doi: 10.2307/I25 I 866

LOPEZ, L.E., Kundu, S.K., Ciravegna, L. (2009) Born global or born regional? Evidences from an exploratory study in the Costa Rican software industry. Journal of International Business Studies. 40, I228-I238. doi: I0.1057/jibs.2008.69

MATHEWS, J. (2006) Dragon Multinationals: new players in 2 I st century globalization.Asia Pacific Journal of Management, 23(I): 5-27. doi: I0.1007/s I0490-006-6 I I3-0

MALDONADO, M.; Dias, D.; Varvakis, D. (2009). Managing Innovation in Small High-technology Firms: A Case Study in Brazil. Journal of Technology Management \& Innovation, 4 (2), I30-| 42. doi: I0.4067/S07 |8-272420090002000 I I
O'MALLEY, E.; O'GORMAN, C. (200I) Competitive advantages in the Irish indigeneous software industry and the role of inward foreign direct investment. European Planning Studies. 9(3), 303-32I. doi: 10.1080/7 I3666484

OJALA, A. (2008). Internationalization of Software Firms - Finnish Small and Medium Sized Software Firms in Japan, Jyväskylä University. Available online at: https://jyx.jyu. fi/dspace/handle/I23456789//8542. [Accessed September 12th 2014]

OJALA, A.; Kontinen, T. (2010) Distance Factors in the Foreign Market Entry of Software SMES. Software Business, (5I). 49-62. doi: 10.1007/978-3-642-13633-7_5

OVIATT, B.M.; McDougall, P.P. (1994). Toward a Theory of International NewVentures. Journal of International Business Studies, 25 (I), 45-64. doi: I0.1057/palgrave.jibs.8490 I 93

OVIATT, B.M.; McDougall, P.P. (2005). Defining international entrepreneurship and modeling the speed of internationalization. Entrepreneurship Theory and Practice, 29, 537-553. doi: I0. I I I //j. I540-6520.2005.00097.x

PATIBANDLA, M., Petersen, B. (2002) Role of transnational corporations in the evolution of high-tech industry: The case of India's software industry. World Development, 30(9), |56|-|577. doi: 10.1016/S0305-750X(02)00060-8

PATTERSON, P.G.; Cicic, M. (1995). A Typology of Service Firms in International Markets: An Empirical Investigation. Journal of International Marketing, 3 (4), 57-83 . Stable URL: http://www.jstor.org/stable/25048624

PHELLAS C.N.; Bloch A.; Seal C. (20II). Structured methods: interviews, questionnaires and observation, in Seale. Researching Society and Culture, 18I-205. Available online at: http://www.sagepub.com/upm-data/47370_Seale_ Chapter_II.pdf. [Accessed September I2th 2014]

PLA-BARBER, J.; GHAURI, P. (20I2) Internationalization of service industry firms: Understanding distinctive characteristics. The Services Industries Journal. 32(7), $1007-$ I0I0. doi: I0.1080/02642069.20I2.662498

RÖNKKÖ, M.; Peltonen, J. (2010) Internationalization of Software Firms. Lecture Notes in Business Information Processing. Software business. (5I), 38-48. doi: 10.1007/9783-642-13633-7_4

RUOKONEN, M.; Saarenketo, S. (2007). The strategic orientations of rapidly Internationalizing software companies. European Business Review. 21 (I), 17-4I. doi: I0.1108/09555340910925166 
SLATER, S.F, Narver, J.C. (2000) The positive effect of a market orientation on business profitability: A balance replication. Journal of Business Research. 48(I), 69-73. doi: 10.1016/S0148-2963(98)00077-0

SOPHOS BANKING SOLUTIONS (2014) Vision. http:// www.sophosbanking.com/index.php/quienes-somos.html [Accessed April 28th 2014]

SUAREZ, F.D.; Cusumano, M.A; Kahl, S.J. (20I2) Services and the business model of product firms:An empirical analysis of the software industry. Management Science. 59(2), 420-435. Stable URL: http://pubsonline.informs.org/doi/abs//0.1287/ mnsc. II 20.1634

UNCTAD (20I2). Information Economy Report 20I2: The Software Industry and Developing Countries. http://unctad. org/en/PublicationsLibrary/ier20I2_en.pdf [Accessed April 28th 20I4]

YAMAKAWA,Y.; Peng, M.; Deeds, D. (2008).What drives new ventures to internationalize from emerging to developed economies? Entrepreneurship Theory and Practice, 32(I), 59-82. doi: 10.1 I I //j.1540-6520.2007.00216.x 